\title{
HARGA SAHAM PT. UNILEVER, TBK DIPENGARUHI OLEH EARNING PER SHARE MELALUI DEBT TO EQUITY RASIO
}

\author{
Dyah Maharani ${ }^{1)}$ \\ 1) Mahasiswa Program Studi Manajemen FE UNKRIS \\ Eddy Sanusi. $S^{2)}$ \\ 2) Dosen Program Studi Manajemen FE UNKRIS \\ Alamat: Kampus UNKRIS, Jatiwaringin Jakarta Timur \\ Email : eddy.sanusi23@gmail.com
}

\begin{abstract}
The purpose of this study is to analyze stock prices are influenced by earnings per share through debut to equity at PT. Unilever Tbk. This study is a causal associative study with a quantitative approach. The population of this study are companies engaged in the manufacturing, marketing, and distribution of household consumer goods, beverages and food from 2013-2020 listed on the IDX. This sampling used purposive sampling technique and PT. Unilever Tbk as the research sample in this study. The data collection technique was taken from the idx website. The data analysis technique used is the path analysis model test. The results of the study show that the direct effect of partially EPS on stock prices has a positive and significant effect, DER on stock prices has a negative and significant effect, while EPS on DER has a negative and significant effect while the indirect effect of EPS on stock prices through DER has a significant effect.
\end{abstract}

Keywords: Stock price, earning per share (EPS), debt to equity rasio (DER)

\section{PENDAHULUAN}

Pembangunan suatu negara saat ini memerlukan dana investasi dalam jumlah yang tidak sedikit. Salah satu ciri negara berkembang adalah tingkat tabungan masyarakat masih rendah, sehingga dana untuk investasi menjadi tidak mencukupi, Pengembangan Pasar modal sangat diperlukan dalam perekonomian Indonesia saat ini. Pasar modal merupakan sarana bagi pihak yang membutuhkan dana dan pihak yang mempunyai kelebihan dana untuk melakukan investasi. Investasi pasar modal perlu memiliki sejumlah informasi yang berkaitan dengan indikator harga saham agar investor bisa mengambil keputusan tentang saham yang ingin dan layak dipilih pada perusahaan apa yang ingin diinvestasikan. Harga dari saham atau efek lainnya berfluktuasi sesuai dengan penawaran dan permintaan terhadap faktor yang bersangkutan. Harga dari saham merupakan alat ukur dari pandangan mereka mengenai masa depan perusahaan dan ekonomi pada umumnya. Penilaian saham secara akurat bisa meminimalkan resiko sekaligus dapat membantu investor mendapatkan keuntungan yang sesuai.

Harga saham pada satu waktu tertentu akan bergantung pada arus kas yang diharapkan diterima dimasa depan oleh investor "rata-rata" jika investor membeli saham. Harga saham menjadi aspek penting dalam mengukur kinerja sebuah perusahaan dikarenakan keberhasilan dalam menghasilkan keuntungan akan memberikan kepuasan bagi investor yang rasional. Harga saham yang cukup tinggi akan memberikan keuntungan, yaitu berupa capital gain dan citra yang lebih baik bagi perusahaan 
sehingga memudahkan bagi manajemen untuk mendapatkan dana dari luar perusahaan. Dalam memilih suatu saham, ada 2 metode analisis atau pendekatan yang sering digunakan, yaitu analisis teknikal dan analisis fundamental. Analisa fundamental ialah analisa yang didasarkan dengan kondisi suatu perusahaan, kondisi ekonomi dan industri terkait. Analisa fundamental pada umumnya menggunakan indikator-indikator perusahaan yang tertera melalui laporan keuangan perusahaan seperti earning per share (EPS), debt to equity ratio (DER), dan lain-lainnya.

Rasio yang digunakan dalam penelitian ini salah satunya adalah earning per share. Semakin tinggi earning per share yang diberikan perusahaan akan memberikan pengembalian yang cukup baik. Ini akan mendorong investor untuk melakukan investasi yang lebih besar lagi sehingga harga saham perusahaan akan meningkat.

Rasio yang rendah berarti manajemen belum berhasil untuk memuaskan pemegang saham, sebaliknya dengan rasio yang tinggi, maka kesejahteraan pemegang saham dengan keuntungan yang dididapat. earning per share itu sendiri merupakan pos yang mendapat perhatian cukup besar dalam laporan keuangan. Investor tertarik pada earning per share karena menunjukkan besarnya bagian keuntungan yang diperoleh untuk setiap lembar saham.

Tidak hanya informasi tentang earning per share yang menjadi kebutuhan dasar para investor dalam mengambil keputusan. tentu saja ada indikator lain yang menjadi alat ukur dalam mengukur harga saham selain earning per share yaitu ada debt to equity ratio. Dalam arti luas dikatakan bahwa debt to equity ratio (DER) ini adalah rasio solvabilitas yang digunakan untuk mengukur kemampuan perusahaan untuk membayar seluruh kewajibannya, baik jangka pendek maupun jangka panjang.
Apabila debt to equity ratio yang rendah maka akan meningkatkan respon positif dari pasar dan akan semakin baik kemampuan perusahaan dalam membayar kewajiban jangka panjang karna resiko yang ditimbulkan dari penggunaan pendanaan yang bersumber dari hutang akan berkurang, sehingga saham akan naik. Hal ini menunjukan bahwa debt to equity ratio yang rendah akan membuat harga saham tersebut menjadi meningkat.

Variabel debt to equity ratio (DER) merupakan variabel yang sangat penting untuk diperhatikan. lnvestor tertarik pada debt to equity ratio karena debt to equity ratio merupakan alat pengukur untuk mengetahui apakah dengan hutang yang besar, perusahaan mampu membayar utang-utangnya tersebut. Kasmir (2016) menyatakan bahwa jika hutang perusahaan lebih besar dibandingkan dana yang disediakan pemegang saham, maka semakin besar pula rasio debt to equity ratio. Apabila rasio debt to equity ratio besar maka berkurang pula minat investor untuk melakukan investasi pada perusahaan tersebut. Utang juga menjadi bahan pertimbangan bagi seorang investor untuk menentukan saham pilihan.

Tujuan penelitian ini adalah untuk mengetahui harga saham PT. Unilever, Tbk dipengaruhi oleh earning per share melalui debt to equity rasio.

\section{LANDASAN TEORI}

\section{Harga Saham}

Harga saham adalah harga yang ditentukan oleh investor melalui pertemuan permintaan dan penawaran. Pertemuan ini dapat terjadi karena para investor sepakat terhadap harga suatu saham. Harga saham merupakan harga penutupan pasar saham selama periode pengamatan untuk tiap-tiap jenis saham yang dijadikan sampel dan pergerakannya senantiasa diamati oleh para investor. Pertemuan ini dapat terjadi karena para investor sepakat terhadap harga suatu 
saham. Menurut Aziz (2015) "harga saham adalah harga pada pasar ril, dan merupakan harga yang paling mudah ditentukan karena merupakan harga dari suatu saham pada pasar yang sedang berlangsung atau jika pasar ditutup, maka harga pasar adalah harga penutupnya”. "Harga saham merupakan cerminan dari kegiatan pasar modal secara umum. Peningkatan harga saham menunjukkan kondisi pasar modal sedang bullish, sebaliknya jika menurun menunjukkan kondisi pasar modal sedang bearish (Triana 2017)".

Ada pula teori lain menurut Sartono (2011) yang menyatakan bahwa harga saham terbentuk melalui mekanisme permintaan dan penawaran di pasar modal. Apabila suatu saham mengalami kelebihan permintaan, maka harga saham cenderung naik. Sebaliknya, apabila kelebihan penawaran maka harga saham cenderung turun. Menurut Hartono (2013) pengertian dari harga saham adalah "Harga suatu saham yang terjadi di pasar bursa pada saat tertentu yang ditentukan oleh pelaku pasar dan ditentukan oleh permintaan dan penawaran saham yang bersangkutan di pasar modal". Sedangkan menurut Brigham dan Houston (2011) "Harga saham menentukan kekayaan pemegang saham. Maksimalisasi kekayaan pemegang saham diterjemahkan menjadi maksimalkan harga saham perusahaan. Harga saham pada satu waktu tertentu akan bergantung pada arus kas yang diharapkan diterima di masa depan oleh investor "rata-rata" jika investor membeli saham". Harga saham tersebut di tentukan oleh pelaku pasar itu sendiri. Harga saham pada satu waktu tertentu akan bergantung pada arus kas yang diharapkan diterima dimasa depan oleh investor "rata-rata" jika investor membeli saham. Berdasarkan pengertian para ahli diatas maka dapat disimpulkan bahwa harga saham adalah harga yang terbentuk sesuai permintaan dan penawaran dipasar jual beli saham dan biasanya merupakan harga penutupan.

Dalam menentukan sebuah pembelian harga saham tiap investor harus memiliki pemahaman tentang berbagai jenis harga saham. Ada pula teori menurut Kasmir (2016) yang menjelaskan tentang jenis-jenis harga saham, yaitu: 1). Dari segi cara peralihannya: a). Saham Atas Unjuk (Bearer Stocks); Merupakan saham yang tidak mempunyai nama atau tidak tertulis nama pemilik dalam saham tersebut. Saham jenis ini mudah untuk dialihkan kepada pihak lain diperlukan syarat dan prosedur tertentu. b). Saham Atas Nama (Registered Stocks); Di dalam saham tertulis nama pemilik saham tersebut dan untuk dialihkan kepada pihak lain diperlukan syarat dan prosedur tertentu. 2). Dari segi hak tagihnya: a). Saham Biasa (Common Stock); Bagi pemilik saham ini hak untuk memperoleh deviden akan didahulukan lebih dahulu kepada saham preferen. Begitu pula dengan hak terhadap harta apabila perusahaan dilikuidasi. b). Saham Preferen (Preffered Stock); Merupakan saham yang memperoleh hak utama dalam deviden dan harta apabila perusahaan dilikuidasi".

Selain mengetahui tentang jenisjenis harga saham seorang investor juga harus mengetahui faktor-faktor lain yang mempengaruhi sebuah harga saham. Terdapat beberapa faktor yang dapat mempengaruhi fluktuasi harga saham dipasar modal, hal ini terjadi karena harga saham dapat dipengaruhi oleh faktor eksternal dari perusahaan maupun faktor internal perusahaan. Menurut Brigham dan Houston (2011) harga saham dipengaruhi oleh beberapa faktor utama yaitu: 1). Faktor Internal;

a). Pengumuman tentang pemasaran produksi penjualan seperti pengiklanan, rincian kontrak, perubahan harga, penarikan produk baru, laporan produksi, laporan keamanan, dan laporan penjualan. b). Pengumuman pendanaan seperti 
pengumuman yang berhubungan dengan ekuitas dan hutang.

c).

Pengumuman badan direksi manajemen (management board of director anouncements) seperti perubahan dan peganti direktur, manajemen dan stuktur organisasi. d). Pengumunnan pengambilan alihan diverifikasi seperti laporan mergerinvestasi, investasi ekuitas, laporan take over oleh pengakusisi dan diakusisi, laporan investasi dan lainnya. Pengumuman lnvestasi seperti melakukan ekspansi pabrik pengembangan riset dan penutupan usaha dan lainnya.

e). Pengumuman ketenaga kerjaan (labour anouncement), seperti negosiasi baru, kontrak baru, pemogokan dan lainnya. f). Pengumuman laporan keuangan perusahaan, seperti peramalaba sebelum akhir tahun viscal dan setelah akhirtahun viscal. 2). Faktor eksternal: a). Pengumuman dari pemerintah seperti perubahan suku bunga tabungan dan deposito kurs valuta asing, inflasi, serta berbagai regulasi dan regulasi ekonomi yang dikeluarkan oleh pemerintah. b). Pengumuman hukum seperti tuntutan terhadap perusahaan atau terhadap manajernya dan tuntutan perusahaan terhadap manajernya. c). Pengumuman industri sekuritas, seperti laporan pertemuan tahunan insider trading, volume atau harga saham perdagangan pembatasan atau penundaan trading".

Faktor-faktor yang dapat mempengaruhi harga saham yaitu menurut Sunariyah (2011), faktor-faktor yang mempengaruhi harga saham adalah: "Faktor lnternal perusahaan, merupakan faktor yang berhubungan dengan kebijakan lnternal pada suatu perusahaan beserta kinerja yang telah dicapai. Hal ini berkaitan dengan hal-hal yang seharusnya dapat dikendalikan oleh manajemen, sedangkan faktor eksternal yaitu hal-hal diluar kemampuan perusahaan atau diluar kemampuan manajemen, misalnya: psikologi pasar, dan laju inflasi yang tinggi".
Selain jenis dan faktor mengenai harga saham ada pula aspek penting yang perlu diperhatikan oleh investor yaitu pengukuran harga saham. Untuk pengukuran harga saham ada 2 metode analisis atau pendekatan yang sering digunakan, yaitu analisis teknikal dan analisis fundamental. Analisa fundamental ialah analisa yang didasarkan dengan kondisi suatu perusahaan, kondisi ekonomi dan industri terkait. Analisa fundamental pada umumnya menggunakan indikator-indikator perusahaan yang tertera melalui laporan keuangan perusahaan seperti earning per share, debt to equity ratio, dan lainlainnya.

Indikator harga saham dapat dilihat dari nilai harga saham, beberapa nilai harga saham menurut Azis, (2015) ada beberapa nilai yang berhubungan dengan harga saham yaitu: 1). "Nilai Buku (Book Value) adalah nilai saham menurut pembukuan perusahaan emiten. Nilai buku perlembar saham adalah aktiva bersih yang dimiliki oleh pemegang saham dengan memiliki sat lembar saham. 2). Nilai Pasar (Market Value) adalah harga saham yang terjadi dipasar bursa pada saat yang ditentukan oleh permintaan dan penawaran harga saham pelaku pasar. 3). Nilai Intrinsik (Intrinsic Value) adalah sbenarnya/seharusnya dari suatu saham. Nilai intrinsik suatu aset adalah penjumlahan nilai sekarang dari cash flow yang dihasilkan oleh asset yang bersangkutan".

\section{Earning Per Share}

Pengertian earning per share menurut Kasmir (2016) merupakan "Rasio untuk mengukur keberhasilan manajemen dalam mencapai keuntungan pemegang saham".Semakin tinggi nilai earning per share tentu saja menggembirakan pemegang saham karena semakin besar laba yang disediakan untuk pemegang saham. Rasio laba menunjukkan dampak gabungan dari 
likuiditas serta manajemen aktiva dan kewajiban terhadap kemampuan perusahaan menghasilkan laba. Jadi disimpulkan bawah earning per share merupakan suatu rasio yang menunjukan jumlah laba yang didapatkan dari setiap lembar saham yang ada. Earning per share merupakan "salah satu indikator keberhasilan perusahaan, sehingga earning per share yang tinggi akan menarik minat lnvestor" (Syamsuddin, 2011). Sedangkan Menurut Alipudin (2016), earning per share merupakan "rasio untuk mengukur keberhasilan manajemen dalam mencapai keuntungan bagi pemegang saham". Earning per share atau laba per lembar saham menunjukkan besarnya laba bersih perusahaan yang siap dibagikan bagi semua pemegang saham perusahaan atau jumlah uang yang dihasilkan (return) dari setiap lembar saham. Menurut Widoatmodjo dan Priatina (2012), Earning per share "sangat berpengaruh terhadap harga saham. Semakin tinggi nilai earning per share maka akan semakin mahal suatu saham, karena earning per share merupakan salah satu bentuk rasio keuangan untuk menilai kinerja perusahaan". Menurut Hadi (2015) "earning per share Adalah Perbandingan antara laba bersih setelah pajak pada tahun buku terhadap saham yang diterbitkan perusahaan". Dengan demikian, laba per lembar saham menunjukan kemampuan perusahaan dalam memperoleh laba dan mendistribusikan laba yang diraih perusahaan kepada pemegang saham. Lama per lembar saham dapat dijadikan sebagai indikator tingkat nilai perusahaan.

$$
\text { Dalam praktiknya rasio }
$$

profitabilitas yang digunakan perusahaan memiliki beberapa tujuan yang hendak dicapai. Rasio aktivitas juga memberikan banyak manfaat bagi kepentingan perusahaan maupun bagi pihak luar perusahaan, untuk masa sekarang maupun masa yang akan datang. Menurut Kasmir (2016) berikut ini adalah tujuan dari earning per share yaitu: 1). "Untuk mengukur atau menghitung laba yang diperoleh perusahaan dalam satu priode tertentu. 2). Untuk menilai posisi laba perusahaan tahun sebelumnya dengan tahun sekarang. 3). Untuk menilai perkembangan laba dari waktu ke waktu. 4). Untuk menilai besarnya laba bersih sesudah pajak dengan modal sendiri. 5). Untuk mengukur produktivitas seluruh dana perusahaan yang digunakan baik modal pinjaman maupun modal sendiri. 6). Untuk mengukur produktivitas dari seluruh dana perusahaan yang digunakan baik modal sendiri. 7). Untuk mengukur atau menghitung laba yang diperoleh perusahaan dalam satu periode tertentu. 8). Untuk menilai posisi laba perusahaan tahun sebelumnya dengan tahun sekarang. 9). Untuk menilai perkembangan laba dari waktu ke waktu. 10). Untuk menilai besarnya laba bersih sesudah pajak dengan modal sendiri. 11). Untuk mengukur produktivitas seluruh dana perusahaan yang digunakan bank modal pinjaman maupun modal sendiri. 12). Untuk mengukur produktivitas dari seluruh dana perusahaan yang digunakan baik modal sendiri.

Manfaat yang diperoleh adalah untuk: 1). Mengetahui besarnya tingkat laba yang diperoleh perusahaan dalam satu priode. 2). Mengetahui posisi laba perusahaan tahun sebelumnya dan tahun sekarang. 3). Mengetahui perkembangan laba dari waktu ke waktu. 4). Mengetahui besarnya laba bersih sesudah pajak dengan modal sendiri. 5). Mengetahui produkstivitas dari seuluruh perusahaan yang digunakan baik modal pinjaman maupun modal sendiri. 6). Mengetahui besarnya tingkat laba yang diperoleh perusahaan dalam satu periode. 7). Mengetahui posisi laba perusahaan tahun sebelumnya dan tahun sekarang. 8). Mengetahui perkembangan laba dari waktu ke waktu. 9). Mengetahui besarnya laba bersih sesudah pajak dengan modal sendiri. 10). Mengetahui produktivitas 
dari seluruh dana perusahaan yang digunakan baik modal pinjaman maupun modal sendiri".

Menurut Sahar (2012) tujuan earning per share adalah: "sama dengan memuaskan semua kepentingan terkait, sehingga dengan tujuan seperti ini maka semua pihak akan merasakan manfaat keberadaan perusahaan yaitu meningkatkan nilai hidup semua stakeholder bahkan dampak multipliernya secara tidak langsung akan meningkatkan perekonomian dan mutu kehidupan secara nasional". Dapat disimpulkan tujuan dan manfaat earning per share /Nilai Perusahaan adalah nilai perusahaan bertujuan untuk meningkatkan nilai harga saham dan untuk menarik investor sehingga nilai perusahaan tersebut bermanfaat bagi para pemangku kepentingan dalam suatu perusahaan itu sendiri.

Earning per share atau laba per saham adalah tingkat keuntungan bersih untuk tiap lembar sahamnya yang mampu diraih perusahaan pada saat menjalankan operasinya. Laba per lembar saham atau earning per share diperoleh dari laba yang tersedia bagi pemegang saham biasa yang beredar. Adapun faktor-faktor yang mempengaruhi earning per share.

Brigham \& Houston (2011) yaitu: 1). "Faktor penyebab kenaikan laba per saham: a). Laba bersih meningkat, jumlah saham yang beredar tetap. b). Laba bersih meningkat, jumlah saham beredar turun / berkurang. c). Laba bersih meningkat, jumlah saham beredar meningkat, tetapi perusahaan tetap mampu mencetak kenaikan laba bersih yang naik secara signifikan. d) Persentase penurunan laba bersih lebih besar dari pada persentase kenaikan jumlah lembar saham biasa yang beredar. e) Persentase penurunan jumlah lembar saham biasa yang beredar lebih besar dari pada persentase penurunan laba bersih. 2). Faktor penyebab penurunan Laba Per Saham dapat disebabkan karena: a). Laba bersih tetap dan jumlah lembar saham biasa yang beredar naik. b). Laba bersih turun dan jumlah lembar saham biasa yang beredar tetap. c). Laba bersih turun dan jumlah lembar saham biasa yang beredar naik. d). Persentase penurunan laba bersih lebih besar dari pada persentase penurunan jumlah lembar saham biasa yang beredar. e). Persentase kenaikan jumlah saham biasa yang beredar lebih besar dari pada persentase kenaikan laba bersih".

Indikator earning per share; Menurut Kasmir (2016), earning per share merupakan "Rasio untuk mengukur keberhasilan manajemen dalam mencapai keuntungan pemegang saham”.

Rumus dalam menghitung earning per share:

$$
\text { Earning per share }=\quad \frac{\text { laba bersih }}{\text { jumlah saham beredar }}
$$

\section{Debt to Equity Rasio}

Untuk mengukur sejauh mana perusahaan dibiayai dengan utang salah satunya dapat dilihat melalui debt to equity ratio. Debt to equity ratio adalah variabel yang mendefinisikan seberapa banyak proporsi dari modal perusahaan yang sumber pendanaannya berasal dari pinjaman atau kredit. Menurut Kasmir
(2016), menyebutkan bahwa "Debt to equity ratio merupakan rasio yang digunakan untuk mengetahui perbandingan antara total utang dengan modal. Sedangkan menurut Cahyani (2017) "Hutang merupakan sumber pendanaan eksternal yang menjadi salah satu bagian penting bagi suatu perusahaan". Menurut Fahmi (2016) 
mendefinisikan "Debt to equity ratio sebagai ukuran yang dipakai dalam menganalisis laporan keuangan untuk memperlihatkan besarnya jaminan yang tersedia untuk kreditor". Menurut Lukman (2011) "Debt to equity ratio adalah mengukur kemampuan perusahaan dalam menutup sebagian atau seluruh utang-utangnya, baik jangka panjang maupun jangka pendek, dengan dana yang berasal dari modal sendiri."

Kondisi keuangan perusahaan dapat dinilai, salah satunya dengan memperhatikan utang perusahaan. Sedangkan bagi perusahaan debt to equity ratio yang tinggi menunjukan tingginya ketergantungan permodalan perusahaan terhadap pihak luar, sehingga beban perusahaan juga semakin berat. Artinya apabila perusahaan menanggung beban yang besar maka keuntungan yang diperoleh digunakan untuk membayar beban tersebut sehingga keuntungan bagi para pemegang saham akan berkurang akibat kurangnya minat lnvestor terhadap perusahaan tersebut dan berpengaruh terhadap penurunan harga saham perusahaan tersebut. Dengan kata lain, rasio ini mengukur seberapa besar total pasiva yang terdiri atas persentase modal sendiri dibandingkan dengan besarnya hutang. Semakin besar debt to equity ratio suatu perusahaan menunjukkan semakin besarnya penggunaan hutang perusahaan dibandingkan dengan modal sendiri yang dimiliki perusahaan. Penggunaan hutang diharapkan akan menaikkan tingkat pengembalian bagi pemegang saham. Untuk mengembangkan perusahaan dalam menghadapi persaingan, maka diperlukan adanya suatu pendanaan yang bisa digunakan untuk memenuhi kebutuhan tersebut. Sumber-sumber pendanaan perusahaan dapat diperoleh dari perusahaan (internal) dan dari luar perusahaan (eksternal). Pada prakteknya, danadana yang dikelola perusahaan harus dikelola dengan baik, karena masingmasing sumber dana tersebut mengandung kewajiban pertanggung jawaban kepada pemilik dana. Proporsi antara modal sendiri (internal) dan modal pinjaman (eksternal) harus diperhatikan, sehingga dapat diketahui beban perusahaan terhadap para pemilik modal tersebut. Dalam manjemen keuangan proporsi antara jumlah dana dari luar lazim disebut sebagai struktur pendanaan atau struktur modal (capital structure). Dalam mengembangkan capital structure perlu dilakukan analisis dari banyak faktor dengan mempertimbangkan kondisi keuangan perusahaan. Sumber dana dari pihak luar diperoleh dari pinjaman hutang, sedangkan sumber dana dari pihak internal diperoleh dari modal saham dan laba tak dibagi.

Untuk memilih menggunakan modal sendiri atau modal pinjaman haruslah menggunakan beberapa perhitungan. Seperti diketahui bahwa penggunaan modal sendiri atau dari modal pinjaman akan memberikan dampak tertentu bagi perusahaan. Pihak manajemen harus pandai mengatur rasio kedua modal tersebut. Pengaturan rasio yang baik akan memberikan banyak manfaat bagi perusahaan guna menghadapi segala kemungkinan yang akan terjadi. Namun semua kebijakan ini tergantung dari tujuan perusahaan secara keseluruhan. Berikut adalah beberapa tujuan debt to equiy rasio menurut Kasmir (2016). 1). "Untuk mengetahui posisi perusahaan terhadap kewajiban kepada pihak lainnya (kreditor). $\quad 2$ ). Untuk menilai kemampuan perusahaan dalam memenuhi kewajiban yang bersifat tetap. 3). Untuk menilai keseimbangan antara nilai aktiva khususnya aktiva tetap dengan modal. 4). Untuk menilai seberapa besar akiva perusahaan dibiayai oleh hutang. 5). Untuk menilai seberapa besar pengaruh hutang perusahaan terhadap pengelolaan aktiva. 6). Untuk menilai atau mengukur berapa bagian dari setiap rupiah modal sendiri yang dijadikan jaminan hutang jangka panjang. 7 ). Untuk 
menilai berapa dana pinjaman yang segera akan ditagih, terdapat sekian kalinya modal sendiri yang dimiliki.

Manfaat debt to equiy rasio menurut Kasmir (2016) adalah: 1. Untuk menganalisis kemapuan posisi perusahaan terhadap kewajiban kepada pihak lainnya. 2). Untuk menganalisis kemampuan perusahaan terhadap kewajiban yang bersifat tetap. 3). Untuk menganalisis keseimbangan antara nilai aktiva khususnya aktiva tetap dengan modal. 4). Untuk menganalisis seberapa besar akiva perusahaan dibiayai oleh hutang. 5). Untuk menganalisis seberapa besar pengaruh hutang perusahaan terhadap pengelolaan aktiva. 6). Untuk menganalisis atau mengukur berapa bagian dari setiap rupiah modal sendiri yang dijadikan jaminan hutang jangka panjang. 7). Untuk menganalisis berapa dana pinjaman yang segera akan ditagih ada terdapat sekian kalinya modal sendiri yang dimiliki".

Menurut Gill dan Chatton (2016:44) faktor-faktor yang mempengaruhi debt to equity ratio sebagai berikut: 1). "Kenaikan atau penurunan hutang. 2). Kenaikan atau penurunan modal sendiri. 3). Hutang atau modal sendiri tetap. 4). Hutang meningkat lebih tinggi dibandingkan modal sendiri, atau sebaliknya".

Sedangkan Menurut Brigham dan Houston (2013) faktor-faktor yang mempengaruhi debt to equity ratio sebagai berikut: "faktor-faktor yang perlu dipertimbangkan perusahaan mengenai debt to equity ratio adalah stabilitas penjualan, struktur modal, leverage operasi, tingkat pertumbuhan, pajak, pengendalian, sikap manajemen, sikap pemberi pinjaman dan agen pemberi peringkat, kondisi pasar, kondisi internal perusahaan, fleksibilitas keuangan".

Indikator Debt to Equity rasio, menurut Kasmir (2016), menyebutkan bahwa "Debt to equity ratio merupakan rasio yang digunakan untuk mengetahui perbandingan antara total utang dengan modal". Rasio ini berguna untuk mengetahui seberapa besar aktiva perusahaan dibiayai dari utang.

Rumus dalam menghitung Debt To Equity Rasio

$$
\mathrm{DER}=\frac{\text { total hutang }}{\text { modal sendiri }}
$$

Kasmir (2016) juga menjelaskan bahwa "Hasil dari rasio ini akan memberikan arti yang berbeda bagi kreditor dan perusahaan".

\section{METODE PENELITIAN}

Penelitian ini merupakan penelitian asosiatif kausal dengan pendekatan kuantitatif, Populasi penelitian ini adalah perusahaan bergerak dibidang manufaktur, pemasaran,dan distribusi barang konsumsi rumah tangga, minuman dan makanan dari tahun 2013-2020 PT. Unilever Tbk yang terdaftar di BEI. Teknik pengumpulan data diambil dari website idx. Teknik analisis data yang digunakan adalah uji model analisis path. (Ghozali, 2014).

\section{HASIL PENELITIAN DAN PEMBAHASAN}

\section{Hasil Penelitian}

\section{Harga saham}

Harga saham adalah bentuk penjualan hak kepemilikan perusahaan kepada pihak lain. Harga saham bisa mengalami kenaikan atau penurunan dengan cepat, hal itu dapat disebabkan karena faktor internal atau faktor eksternal 
Tabel 1: Data Harga Saham PT. Unilever tbk

\begin{tabular}{lllllllll}
\hline \multicolumn{1}{c}{ TRIWULAN } & \multicolumn{7}{c}{ TAHUN } \\
\hline & $\mathbf{2 0 1 3}$ & $\mathbf{2 0 1 4}$ & $\mathbf{2 0 1 5}$ & $\mathbf{2 0 1 6}$ & $\mathbf{2 0 1 7}$ & $\mathbf{2 0 1 8}$ & $\mathbf{2 0 1 9}$ & $\mathbf{2 0 2 0}$ \\
\hline I & 4560 & 5850 & 7930 & 8585 & 8665 & 9905 & 9845 & 7250 \\
II & 6150 & 5855 & 7900 & 9015 & 9760 & 9220 & 9000 & 7900 \\
II & 6030 & 6360 & 7600 & 8910 & 9795 & 9405 & 9300 & 8100 \\
IV & 5200 & 6460 & 7400 & 7760 & 11180 & 9080 & 8400 & 7350 \\
\hline Rata-Rata & $\mathbf{5 4 8 5}$ & $\mathbf{6 1 3 1}$ & $\mathbf{7 7 0 8}$ & $\mathbf{8 5 6 8}$ & $\mathbf{9 8 5 0}$ & $\mathbf{9 4 0 3}$ & $\mathbf{9 1 3 6}$ & $\mathbf{7 6 5 0}$ \\
\hline
\end{tabular}

Sumber: www.idx.com

Berdasarkan Tabel 1, Harga saham PT. Unilever Tbk mengalami fluktuasi dari tahun 2013 sampai dengan tahun 2020. Dapat dilihat pada grafik diatas tingkat rata-rata harga saham tahun 2013 adalah sebesar Rp 5485. Tahun 2014 tingkat rata-rata Harga Saham adalah sebesar Rp 6131. Tahun 2015 tingkat ratarata Harga Saham adalah sebesar Rp 7708. Tahun 2016 tingkat rata-rata harga saham adalah sebesar Rp 8568. Tahun 2017 tingkat rata-rata harga saham adalah sebesar Rp 9850. Tahun 2018 tingkat ratarata harga saham adalah sebesar Rp 9403. Tahun 2019 tingkat rata-rata harga saham adalah sebesar Rp 9136 dan Tahun 2020 tingkat rata-rata harga saham adalah sebesar Rp 7650. Pada analisis diatas disimpulkan tahun 2017 tingkat rata-rata harga saham menjadi yang tertinggi yaitu sebesar Rp 9850 dan yang terendah yaitu tahun 2013 sebesar Rp 5484. Terlihat pada tahun 2017 tingginya harga saham mencerminkan tingginya permintaan saham pada saat itu diikuti dengan menurut informasi dari Badan Pusat Statistik Pertumbuhan ekonomi tercatat $5,17 \%$ meningkat dibandingkan dengan pertumbuhan tahun sebelumnya sebesar $5,07 \%$ ditopang oleh permintaan domestik pada 2017 bertumbuh sebesar 5,62\% meningkat dari tahun sebelumnya sebesar 5,13\% sedangkan pada tahun 2013 rendahnya harga saham mencerminkan rendahnya permintaan saham pada saaat itu diikuti dengan menurut informasi Badan Pusat Statistik pertumbuhan ekonomi pada tahun 2013 tercatat 4,8\% melambat jika dibandingkan dengan pertumbuhan ekonomi tahun sebelumnya sebesar 5,0\% hal ini dipicu karena konsumsi RT sebesar 4,96\% lebih rendah dibandingkan dengan tahun 2012 yang mencapai $5,16 \%$ serta penurunan ekspor $14,62 \%$ dari tahun sebelumnya.

\section{Earning Per Share}

Earning per share yang besar menandakan kemampuan yang lebih besar dalam menghasilkan keuntungan bersih dari setiap lembar saham. Peningkatan earning per share menandakan perusahaan berhasil meningkatkan taraf kemakmuran investor, dan hal ini akan mendorong investor untuk menambah jumlah modal yang ditanamkan.

Tabel 2: Data EPS PT. Unilever Tbk

\begin{tabular}{lcccccccc}
\hline TRIWULAN & \multicolumn{7}{c}{ TAHUN } \\
\hline & $\mathbf{2 0 1 3}$ & $\mathbf{2 0 1 4}$ & $\mathbf{2 0 1 5}$ & $\mathbf{2 0 1 6}$ & $\mathbf{2 0 1 7}$ & $\mathbf{2 0 1 8}$ & $\mathbf{2 0 1 9}$ & $\mathbf{2 0 2 0}$ \\
\hline I & 188 & 878 & 809 & 206 & 1475 & 1241 & 229 & 49 \\
II & 970 & 1973 & 984 & 932 & 975 & 1463 & 485 & 95 \\
II & 736 & 1531 & 948 & 832 & 1685 & 957 & 722 & 143 \\
IV & 701 & 952 & 1766 & 838 & 918 & 1194 & 969 & 188 \\
\hline Rata-Rata & $\mathbf{6 4 9}$ & $\mathbf{1 3 3 4}$ & $\mathbf{1 1 2 7}$ & $\mathbf{7 0 2}$ & $\mathbf{1 2 6 3}$ & $\mathbf{1 2 1 4}$ & $\mathbf{6 0 1}$ & $\mathbf{1 1 9}$ \\
\hline \multicolumn{5}{l}{ Sumber: Laporan Keuangan EPS PT.Unilever Tbk }
\end{tabular}


Berdasarkan tabel 2, earning per share mengalami fluktuatif atau naik turunnya earning per share dari tahun 2013-2020. Bisa dilihat pada grafik diatas tingkat rata-rata EPS pada tahun 2013 adalah sebesar Rp. 649. Lalu tahun 2014 tingkat rata-rata EPS adalah sebesar Rp. 1334. Tahun 2015 tingkat rata-rata EPS adalah sebesar Rp. 1127. Tahun 2016 tingkat rata-rata EPS adalah sebesar Rp. 702. Tahun 2017 tingkat rata-rata EPS adalah sebesar Rp. 1263. Tahun 2018 tingkat rata-rata EPS adalah sebesar Rp.1214. Tahun 2019 tingkat rata-rata EPS adalah sebesar Rp. 601. Dan tahun 2020 tingkat rata-rata EPS adalah sebesar 119. Pada analisis diatas bisa disimpulkan pada tahun 2014 tingkat rata-rata EPS menjadi yang tertinggi yaitu sebesar Rp.1334. dan yang terendah yaitu pada tahun 2020 sebesar Rp. 119. Naik turunnya EPS disebabkan oleh laba perusahaan yang terus dihasilkan oleh penjualan kemampuan perseroan untuk mengelola beban produksi,beban usaha dan biaya keuangan dengan baik. Semakin tinggi EPS suatu perusahaan mencerminkan semakin besar keuntungan yang diterima oleh pemegang saham.

\section{Debt to Equity Rasio}

Jika rasio ini tinggi artinya pendanaan perusahaan lebih besar dengan utang dibandingkan dengan modal sendiri maka semakin besar risiko yang ditanggung perusahaan hal itu menjadi sulit bagi perusahaan jika ingin memperoleh tambahan pinjaman. Sebaliknya jika rasio ini rendah maka risiko yang ditanggung perusahaan lebih kecil karena perusahaan lebih mengandalkan modal sendiri dibandingkan dengan utang sebagai sumber pendanaan.

Tabel 3: Data DER PT. Unilever Tbk

\begin{tabular}{|c|c|c|c|c|c|c|c|c|}
\hline TRIWULAN & & & & TAI & IUN & & & \\
\hline & 2013 & 2014 & 2015 & 2016 & 2017 & 2018 & 2019 & 2020 \\
\hline I & 1,719 & 1,646 & 1,751 & 1,624 & 1,342 & 1,530 & 1,698 & 1,504 \\
\hline II & 1,427 & 1,366 & 1,376 & 1,349 & 1,341 & 1,323 & 1,303 & 1,702 \\
\hline II & 1,704 & 1,564 & 1,563 & 1,349 & 1,518 & 1,813 & 1,411 & 1,444 \\
\hline IV & 1,468 & 1,475 & 1,443 & 1,391 & 1,337 & 1,634 & 1,344 & 1,317 \\
\hline Rata-Rata & $\mathbf{1 , 5 8 0}$ & 1,513 & 1,533 & 1,428 & 1,385 & 1,575 & 1,439 & 1,492 \\
\hline
\end{tabular}

Berdasarkan Tabel 3, debt to equity rasio PT.Unilever Tbk mengalami fluktuatif atau naik turun dari tahun 2013 sampai dengan 2020. Bisa dilihat pada grafik diatas tingkat rata-rata DER tahun 2013 adalah sebesar 1,580. Lalu pada tahun 2014 tingkat rata-rata DER adalah sebesar 1,513. Tahun 2015 tingkat ratarata DER adalah sebesar 1,533. Tahun 2016 tingkat rata-rata DER adalah sebesar 1,428. Tahun 2017 tingkat rata-rata DER adalah sebesar 1,385. Tahun 2018 tingkat rata-rata DER adalah sebesar 1,575. Tahun 2019 tingkat rata-rata DER adalah sebesar 1,439. Dan tahun 2020 tingkat rata-rata DER adalah sebesar 1,492. Pada analisis diatas bisa disimpulkan pada tahun 2013 tingkat rata-rata DER menjadi yang tertinggi yaitu sebesar 1,580 dan yang terendah yaitu pada tahun 2017 sebesar 1,385. Peningkatan DER disebabkan oleh nilai ekuitas yang lebih rendah dibandingkan nilai kewajiban/utang perusahaan serta menurunnya DER dikarenakan nilai kewajiban/utang perusahaan mengalami penurunan dan nilai ekuitas perusahaan meningkat. 
Tingginya ketergantungan permodalan perusahaan terhadap pihak luar sehingga beban perusahaan semakin berat. Yang akhirnya akan mengurangi hak pemegang saham dalam bentuk dividen sehingga mengurangi minat investor dalam menanamkan dananya dalam perusahaan.

\section{Analisis Jalur}

Uji model dalam penelitian ini menggunakan analisis jalur (path analysis), Ghozali (2014) menyatakan bahwa model analisis jalur (path analysis) digunakan untuk mengetahui pengaruh langsung atau tidak langsung seperangkat variabel bebas terhadap variabel terikat. Dalam pengujian ini ada tiga model analisis jalur yang akan dilakukan yaitu:

Model 1 Pengaruh Earning Per Share dan Debt to Equity Rasio Terdahap Harga saham

Tabel 4: Hasil Analisis Uji Model 1

\begin{tabular}{lccc}
\hline \multirow{2}{*}{ Variabel } & \multicolumn{3}{c}{ Parameter } \\
\cline { 2 - 4 } & $\begin{array}{c}\text { Koefisien } \\
\text { Regresi }\end{array}$ & Sig. & $\boldsymbol{\alpha}$ \\
\hline EPS & 1,796 & 0,006 & 0,05 \\
DER & $-3956,164$ & 0,023 & \\
\hline
\end{tabular}

Keterangan: Variabel Harga_Saham

Sumber: data diolah 2021

Berdasarkan Tabel 4, dapat diperoleh persamaan regresi berganda sebagai berikut:

$$
\mathrm{HS}=1,796 \mathrm{EPS}-3956,164 \mathrm{DER}
$$

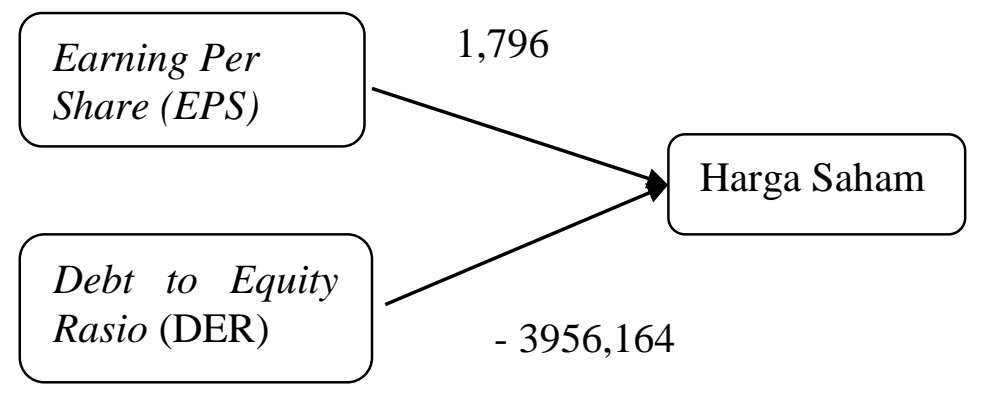

\section{Gambar 1: Hasil Diagram Jalur Model 1}

Terdapat pengaruh signifikan antara earning per share terhadap harga saham PT. Unilever Tbk. Hipotesis ini akan diuji melalui analisis regresi linier sederhana. Berdasarkan hasil pengujian diperoleh persamaan regresi yaitu sebagai berikut:

$\mathrm{HS}=1,796$ EPS

Koefisien Earning Per Share adalah sebesar 1.796. Artinya jika earning per share mengalami kenaikan, maka harga saham akan mengalami peningkatan.
Pada tabel 4, hasil dari uji t yang menunjukkan bahwa nilai profitabilitas signifikansi earning per share sebesar 0.006 yang menunjukkan nilai yang lebih kecil dari signifikasi yang ditentukan yaitu 0.05 yang artinya earning per share berpengaruh terhadap harga saham. Dengan demikian $\mathrm{Ha}$ diterima dan $\mathrm{Ho}$ ditolak, berarti bahwa earning per share berpengaruh signifikan terhadap harga saham. 


\section{Model 2 Pengaruh Earning Per Share Terhadap Debt to Equity Rasio}

Tabel 5: Hasil Analisis Uji Model 2

\begin{tabular}{lccc}
\hline \multirow{2}{*}{ Variabel } & \multicolumn{4}{c}{ Parameter } \\
\cline { 2 - 4 } & $\begin{array}{c}\text { Koefisien } \\
\text { Regresi }\end{array}$ & Sig. & $\boldsymbol{\alpha}$ \\
\hline Ln_EPS & $-0,085$ & 0,029 & 0,05 \\
\hline
\end{tabular}

Keterangan: Variabel Harga_Saham

Sumber: data diolah 2021

Berdasarkan Tabel 5, dapat diperoleh persamaan regresi sebagai berikut:

$$
\text { DER }=-0,085
$$

$\begin{aligned} & \text { Earning Per } \\ & \text { Share (EPS) }\end{aligned} \quad-0,085$

\section{Gambar 2: Hasil Diagram Jalur Model 2}

Terdapat pengaruh signifikan antara debt to equity rasio terhadap harga saham PT. Unilever Tbk. Hipotesis ini akan diuji melalui analisis regresi linier sederhana. Berdasarkan hasil pengujian diperoleh persamaan regresi yaitu sebagai berikut:

$$
\mathrm{HS}=-3956,164 \text { DER } .
$$

Koefisien debt to equity rasio adalah sebesar $(-3956,164)$. Artinya jika debt to equity rasio mengalami penurunan, maka harga saham akan mengalami penurunan.
Pada tabel 4, hasil dari uji t yang menunjukkan bahwa nilai profitabilitas signifikansi debt to equity rasio sebesar 0.023 yang menunjukkan nilai yang lebih kecil dari signifikasi yang ditentukan yaitu 0.05 yang artinya debt to equity rasio berpengaruh terhadap harga saham. Dengan demikian $\mathrm{Ha}$ diterima dan $\mathrm{Ho}$ ditolak, hal ini berarti bahwa debt to equity rasio berpengaruh signifikan terhadap harga saham.

\section{Model 3 hasil dari model 1 dan 2 yaitu pengaruh Earning Per Share terhadap harga} saham melalui Debt To Equity Rasio

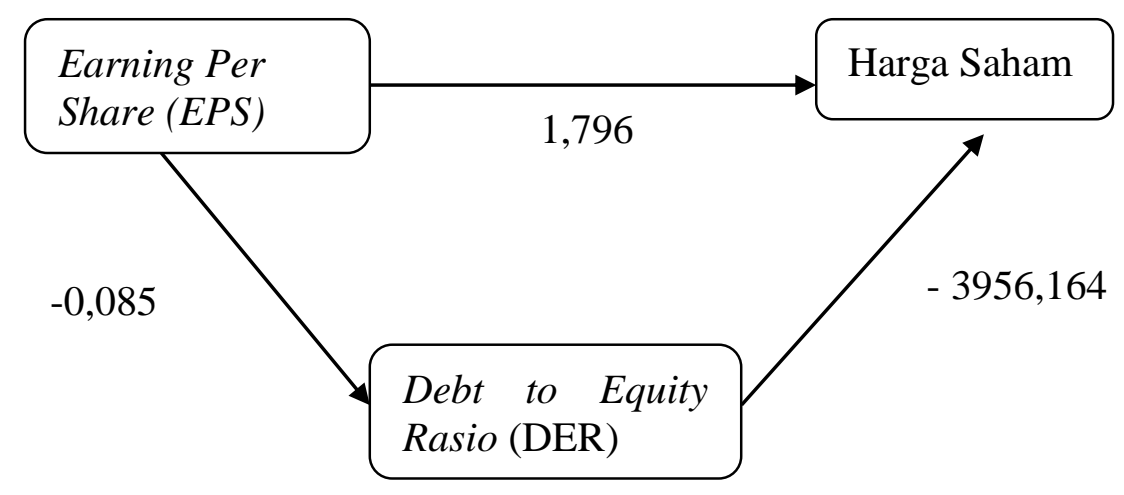

Gambar 3: Hasil Diagram Jalur Model 3 
Terdapat pengaruh signifikan antara earning per share terhadap debt to equity rasio PT. Unilever Tbk. Hipotesis ini akan diuji melalui analisis regresi linier sederhana.

Berdasarkan hasil pengujian diperoleh persamaan regresi yaitu sebagai berikut:

$$
\text { DER }=-0,085 \text { EPS }
$$

Koefisien earning per share adalah sebesar -0,085. Artinya jika earning per share mengalami penurunan, maka debt to equity rasio akan mengalami penurunan.
Pada tabel 5, hasil dari uji t yang menunjukkan bahwa nilai profitabilitas signifikansi earning per share sebesar 0.029 yang menunjukkan nilai yang lebih kecil dari signifikasi yang ditentukan yaitu 0.05 yang artinya earning per share berpengaruh terhadap debt to equity rasio. Hasil uji t menunjukkan bahwa earning per share berpengaruh terhadap debt to equity rasio, Dengan demikian $\mathrm{Ha}$ diterima dan Ho ditolak, berarti bahwa earning per share berpengaruh signifikan terhadap debt to equity rasio.

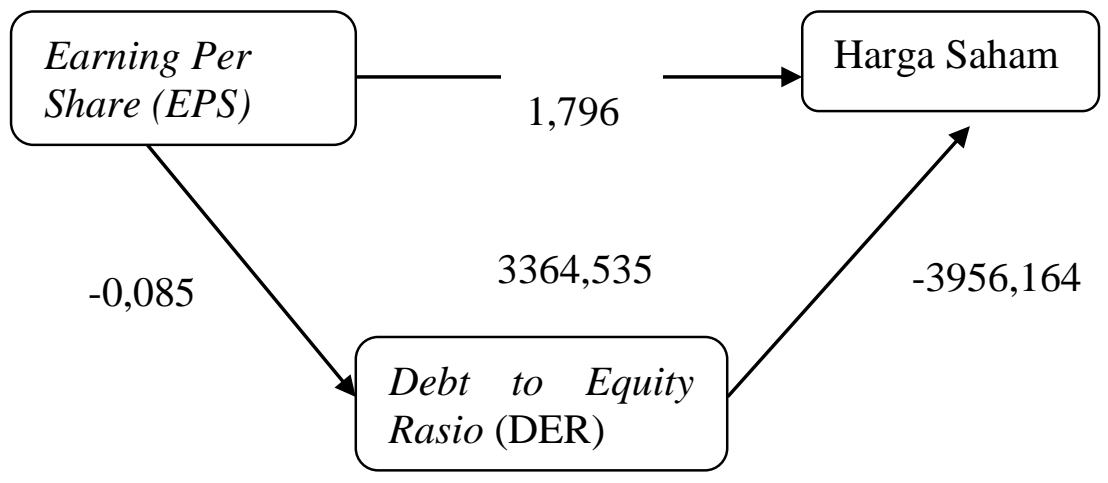

Gambar 4: Hasil Diagram analisis jalur

Terdapat pengaruh signifikan antara earning per share terhadap harga saham melalui debt to equity rasio pada PT.Unilever Tbk. Pada uji ini akan membuktikan pengaruh langsung earning

Analisis jalur secara matematis menjadi model regresi standardized (tanpa kostanta) karena ingin membandingkan berbagai jalur. Besarnya koefisien pengaruh langsung dan pengaruh tidak langsung dapat diitung sebagai berikut:

Rumus untuk mencari pengaruh langsung dan pengaruh tidak langsung adalah sebagai berikut: 1). Pengaruh langsung antara earning per share terhadap harga saham adalah 1,796, berpengaruh secara langsung karena tidak melalui variabel intervening. 2). Pengaruh per share terhadap harga saham dengan pengaruh tidak langsung earning per share terhadap harga saham melalui debt to equity rasio.

tidak langsung antara earning per share terhadap harga saham melalui debt to equity rasio adalah $(-0,085 \times-3956,164)$ dan di peroleh hasil sebesar 3362,7394. Dengan demikian pengaruh tidak langsung lebih besar dari pada pengaruh langsung yaitu $3362,7394>1,796$, berarti Ha diterima dan Ho ditolak yaitu adanya pengaruh earning per share terhadap harga saham melalui debt to equity rasio sebagai variabel intervening. 


\section{Pembahasan}

\section{Pengaruh Earning Per Share terhadap Harga Saham PT. Unilever Tbk}

Berdasarkan hasil penelitian menunjukkan bahwa earning per share yang tinggi akan mendorong harga saham semakin tinggi. Semakin besar earning per share menunjukkan kinerja perusahan yang semakin baik karena tingkat pengembalian return semakin besar. Hasil penelitian ini mendukung dengan hasil penelitian yang dilakukan oleh Monica (2020), Ditarosa (2019) dan Sunartyo (2018) yang menyatakan bahwa earning per share berpengaruh positif dan signifikan terhadap harga saham.

\section{Pengaruh Debt to Equity Rasio terhadap Harga Saham PT. Unilever Tbk}

Berdasarkan hasil penelitian menunjukan bahwa debt to equity rasio akan menurunkan terhadap harga saham. Penggunaan utang yang semakin besar dibandingkan dengan modal sendiri mendorong penurunan nilai perusahaan. Hasil penelitian ini mendukung dengan hasil penelitian yang dilakukan oleh Ramadhani (2017), Cahyani (2017) dimana debt to equity rasio memiliki pengaruh negatif signifikan terhadap harga saham.

Pengaruh Earning Per Share terhadap Debt to Equity Rasio PT. Unilever Tbk

Berdasarkan hasil penelitian menunjukan bahwa, semakin rendah earning per share, semakin tinggi debt to equity ratio. Perusahaan menggunakan utang yang lebih sedikit ketika perusahaan memperoleh keuntungan yang tinggi, sehingga lebih memilih menggunakan laba ditahan dari pada utang maupun modal yang dimiliki dalam mendanai perusahaan. Perusahaan dengan laba tinggi tentu memiliki dana internal yang lebih besar dari pada perusahaan dengan laba rendah. Karena itu laba akan berhubungan negatif dengan utang perusahaan. Semakin tinggi keuntungan yang diperoleh berarti semakin rendah kebutuhan dana asing (utang) sehingga semakin rendah pula utangnya.

Hasil penelitian ini mendukung dengan hasil penelitian yang dilakukan oleh Mujati S (2016) yang menyatakan bahwa profitabilitas berpengaruh negatif terhadap struktur modal. Meningkatnya profitabilitas perusahaan akan menyebabkan perusahaan lebih memilih menggunakan modal sendiri yaitu laba.

\section{Pengaruh Earning Per Share terhadap Harga Saham Melalui Debt to Equity Rasio PT. Unilever Tbk}

Berdasarkan hasil penelitian menunjukan bahwa semakin tinggi laba perusahaan yang diberikan kepada para pemegang saham akan menambah daya tarik investor dan mendorong untuk memiliki saham tersebut, sehingga menyebabkan meningkatnya harga saham. Semakin tinggi nilai debt to equity rasio, akan semakin tinggi pula harga saham. Debt to equity ratio mengungkapkan bagaimana penggunaan pendanaan perusahaan dari struktur modal yang dimiliki oleh perusahaan yang berasal dari utang jangka panjang dan modal yang berasal dari ekuitas.

Debt to equity ratio mendukung harga saham, hal ini menunjukkan bahwa investor memperhatikan berapa besar modal yang dibiayai oleh mereka kepada perusahaan untuk menghasilkan laba bersih untuk mereka. Hasil penelitian ini mendukung atau berbeda dengan hasil penelitian yang dilakukan oleh Mujati S (2016). Yang menyatakan adanya pengaruh earning per share terhadap harga saham melalui debt to equity rasio.

\section{KESIMPULAN DAN SARAN}

\section{Kesimpulan}

1). Peningkatan earning per share akan meningkatkan harga saham PT. Unilever Tbk. 2). Peningkatan debt to 
equity ratio akan menurunkan harga saham PT. Unilever Tbk. 3). Peningkatan earning per share akan menurunkan debt to equity ratio PT. Unilever Tbk. 4). Pengaruh tidak langsung ini menunjukkan bahwa adanya dukungan earning per share terhadap harga saham PT. Unilever Tbk melalui debt to equity ratio.

\section{Saran}

$\begin{array}{cc}\text { Pada } & \text { penelitian yang } \\ \text { dilaksanakan } & \text { kemudian }\end{array}$ memperoleh kesimpulan hasil penelitian, Selanjutnya penulis ingin memberikan saran kepada PT.Unilever Tbk agar bisa menjadi masukan dan perhatian lebih untuk perusahaan: 1). Pada perusahaan sebaiknya memaksimalkan revenue (pendapatan) untuk mendapatkan EPS yang stabil. Dikarenakan EPS perusahaan akan menjadi fokus utama investor dalam berinvestasi. Semakin tinggi nilai EPS tentunya akan menarik minat investor dan akan meningkatkan harga saham perusahaan. 2). Sebaiknya perusahaan tidak memiliki hutang dalam jumlah yang sangat besar atau melebihi ekuitas (modal) yang dimiliki perusahaan. Selain itu untuk mengurangi penggunaan hutang, perusahaan dapat memanfaatkan modal sendiri atau laba ditahan. Perusahaan yang dapat menjaga nilai DER dibawah batas optimum akan menarik investor untuk berinvestasi sebab resikonya yang tidak terlalu besar. 3). Variabel EPS berpengaruh negatif dan signifikan terhadap DER, disarankan agar penelitian selanjutnya menggunakan variabel lainnya agar hasil penelitian berpengaruh positif secara signifikan terhadap variabel DER. 4). Bagi investor disarankan agar dalam melakukan penilaian terhadap perusahaan sebaiknya juga memperhatikan faktor lainnya yang mempengaruhi harga saham perusahaan seperti likuiditas, pertumbuhan perusahaan, maupun faktor eksternal perusahaan lainnya.

\section{DAFTAR PUSTAKA}

Alipudin, Asep. 2016. "Pengaruh EPS, ROE, ROA dan DER Terhadap Harga Saham pada Perusahaan sub sektor semen yang terdaftar di BEI." JIAFE (Jurnal Ilmiah Akuntansi Fakultas Ekonomi) 2.1 (2016): 1-22.

Aziz, Musdalifah, dkk. 2015. Manajemen Investasi Fundamental, Teknikal, Perilaku Investor, dan Return Saham.Cetakan pertama.Edisi pertama. Jakarta: Deepublish.

Brigham dan Houston. 2011. Dasar-dasar Manajemen Keuangan Buku 1 (edisi II). Jakarta: Salemba Empat.

Chatton, Moira, 0.Gill. James. 2016. Memahami Laporan Keuangan. Jakarta: PPM Manajemen, ISBN10: 1426018509

Cahyani, N. dan Winarto, H., 2017. Pengaaruh Return On Equity, Earning Per Share, dan Debt to Equity Ratio Terhadap Harga Saham pada PT Medco Energi Internasional Tbk. Jurnal Manajemen Bisnis Krisnadwipayana, 5(2).

Fahmi, Irham. 2016. Pengantar Manajemen Keuangan. Bandung: ALFABETA, CV

Ghozali, Imam. 2014. Structural Equation Modeling, Metode Alternatif dengan Partial Least Square (PLS). Edisi 4.Semarang: Badan Penerbit Universitas Diponegoro.

Hadi, Nor. 2013. Pasar Modal Acuan Teoretis dan Praktis Investasi di Instrument Keuangan Pasar Modal. Yogyakarta: Graha Ilmu.

Hartono, J. (2013). Teori Portofolio dan Analisis Investasi, Edisi Kedelapan. Yogyakarta: BPFE.

Jatmika, Ditarosa Taurista, et al. 2019. "The Effect of Return on Asset, Return on Equity, and Earning Per Share in the Stock Prices of Tourism and Hospitality Companies Listed in 
the Indonesia Stock Exchange 20132017." Journal of World Conference (JWC). Vol. 1. No. 2. 2019.

Kasmir. 2016. Analisis Laporan Keuangan. Jakarta: Raja Grafindo Persada

Monica, Novia Chris, and Nanu Hasanuh. "The Effect of Return on Assets, Return on Equity and Earning Per Share on Stock Price." Jurnal Ilmiah MEA (Manajemen, Ekonomi, \& Akuntansi) 4.3 (2020): 1506-1515.

Mujati, S., Yuniep dan Meida Dzulqodah. 2016. "Pengaruh Earning Per Share Dan Price Earning Ratio Terhadap Debt To Equity Ratio Dan Harga Saham Pada Perusahaan Sektor Makanan Dan Minuman Di Bursa Efek Indonesia." Eksis: Jurnal Riset Ekonomi dan Bisnis 11.1 (2016).

Ramadhani, Hudaya Fendi. 2017. Pengaruh Debt to Equity Ratio (DER), Return on Equity (ROE) dan Net Profit Margin (NPM) terhadap Harga Saham Perusahaan Sektor Pertambangan yang Terdaftar di Bursa Efek Indonesia. Periode 2011-

2015. Skripsi. Yogyakarta. Universitas Negeri Yogyakarta. ,

Sartono. 2011. Manajemen Keuangan (Teori dan Aplikasi). Edisi keempat.
Cetakan ketujuh. Yogyakarta : BPFE Yogyakarta.

Sahar, Sarjono (2012). HOKI Seтua Orang Berhak Meraih Keberuntungan, Jakarta: PT. Gramedia.

Sunariyah. 2011. Pengantar Pengetahuan Pasar Modal, Edisi ke empat. Yogyakarta: Unit Penerbit dan Percetakan AMP YKPN.

Sunartiyo, T. 2018. "Effect of Inflation, Earning Per Share (EPS), Price Earnings Ratio (PER) on Stock Price PT. Siantar Top, Tbk." International Journal of Business and Applied Social Science (IJBASS) 4.9 (2018).

Syamsuddin, Lukman, 2011, Manajemen Keuangan Perusahaan, Edisi Baru, Jakarta: PT. Raja Grafindo Persada.

Triana, Fuji. pengaruh Net Profit Margin (NPM) Dan Debt To Equity Ratio (DER) Terhadap Harga Saham (Studi Kasus Pada Perusahaan Indeks LQ 45 Yang Terdaftar Di Bursa Efek Indonesia Tahun 20122015). Diss. Universitas Komputer Indonesia, 2018.

Widoatmodjo, Sawidji. 2012. Cara Sehat Investasi di Pasar Modal. Edisi Revisi. Jakarta: PT. Jurnalindo Aksara Grafika. 